\title{
The Conundrum of Solving 'Too Big to Fail' in the European Union: Supranationalization at Different Speeds
}

Citation for published version (APA):

Quaglia, L., \& Spendzharova, A. (2017). The Conundrum of Solving 'Too Big to Fail' in the European Union: Supranationalization at Different Speeds. Journal of Common Market Studies, 55(5), 1110-1126. https://doi.org/10.1111/jcms.12531

Document status and date:

Published: 01/09/2017

DOI:

10.1111/jcms. 12531

Document Version:

Publisher's PDF, also known as Version of record

Document license:

Taverne

Please check the document version of this publication:

- A submitted manuscript is the version of the article upon submission and before peer-review. There can be important differences between the submitted version and the official published version of record.

People interested in the research are advised to contact the author for the final version of the publication, or visit the DOI to the publisher's website.

- The final author version and the galley proof are versions of the publication after peer review.

- The final published version features the final layout of the paper including the volume, issue and page numbers.

Link to publication

\footnotetext{
General rights rights.

- You may freely distribute the URL identifying the publication in the public portal. please follow below link for the End User Agreement:

www.umlib.nl/taverne-license

Take down policy

If you believe that this document breaches copyright please contact us at:

repository@maastrichtuniversity.nl

providing details and we will investigate your claim.
}

Copyright and moral rights for the publications made accessible in the public portal are retained by the authors and/or other copyright owners and it is a condition of accessing publications that users recognise and abide by the legal requirements associated with these

- Users may download and print one copy of any publication from the public portal for the purpose of private study or research.

- You may not further distribute the material or use it for any profit-making activity or commercial gain

If the publication is distributed under the terms of Article $25 \mathrm{fa}$ of the Dutch Copyright Act, indicated by the "Taverne" license above, 


\title{
The Conundrum of Solving 'Too Big to Fail' in the European Union: Supranationalization at Different Speeds*
}

\author{
LUCIA QUAGLIA ${ }^{1}$ and ANETA SPENDZHAROVA ${ }^{2}$ \\ ${ }^{1}$ University of York ${ }^{2}$ Maastricht University
}

\begin{abstract}
In the aftermath of the international financial crisis, the European Union (EU) adopted a series of regulatory reforms concerning capital adequacy, bank structures and resolution in order to tackle the risks created by financial institutions that were 'too big to fail'. This article demonstrates different degrees of progress towards a supranational framework in two important areas of reform: Limited harmonization of the rules on bank structures, but robust progress toward the supranationalization of bank resolution, where the euro area dimension is also considered. What accounts for this variation? We draw on a synthesis of neofunctionalism and liberal intergovernmentalism to explain the diverging outcomes. We explain the low supranationalization in bank structural reforms with the absence of strong spillovers and availability of domestic options to unilaterally contain financial instability. In bank resolution, we examine the causal mechanisms through which significant spillovers modified the government preferences of key Member States.
\end{abstract}

Keywords: European Union bank regulation; too big to fail; bank resolution; bank structures

\section{Introduction}

The international financial crisis highlighted that some banks and financial institutions were 'too big, too complex, and too interconnected to fail' (De Larosière, 2009; FSA, 2009; Liikanen, 2012). These banks, which are generally referred to as 'too big to fail', have posed a major public policy problem. The Chairman of the Federal Reserve, Ben Bernanke argued that 'too-big-to-fail financial institutions were both a source (though by no means the only source) of the crisis and among the primary impediments to policymakers' efforts to contain it' (Bernanke, 2010). In the European Union (EU), the high level group of experts chaired by Jacques De Larosière (2009, p. 62) pointed out that banks too big to fail 'can expose the rest of society to major costs and are subject to acute moral hazard; in some instances, these institutions can even be "too big to save".

In the aftermath of the crisis, EU policy-makers first introduced reforms to shore up banks' capital adequacy (Howarth and Quaglia, 2013). In addition, they singled out two areas of regulatory reform as particularly important in order to tackle the policy problem of 'too big to fail': Bank resolution and bank structures. As the literature has already examined the EU capital adequacy reforms, we focus on the latter two areas. We analyze

\footnotetext{
*The authors would like to thank Benjamin Braun, Andrew Baker and Scott James for their valuable comments on previous versions of the manuscript as well as participants in the workshop 'The Politics of Central Banking' held during the 2016 ECPR Joint Sessions of Workshops in Pisa, the $8^{\text {th }}$ Pan-European conference on the European Union held in Trento in 2016 and two anonymous JCMS referees for their constructive feedback. Lucia Quaglia was a research fellow at the Hanse Wissenschaft Kolleg and the BIGSSS at the University of Bremen when this paper was completed.
} 
the degree of supranationalization, meaning the degree of harmonization of national legislation imposed by the new EU rules, the creation of new EU institutions and transfer of powers and competences from the Member States to the EU. The two areas have followed different trajectories of reform and, importantly for our analysis, have reached different levels of supranationalization even though they are intended to address the same underlying problem of banks that are 'too big to fail'.

In the realm of bank structural reforms, the proposed EU legislation (not agreed yet) introduces only minimum harmonization of national legislation. Furthermore, it does not create new EU institutions or stipulate a transfer of powers or competencies from the national level to the EU level (Hardie and Macartney, 2016). Concerning the reform of bank resolution, two pieces of legislation were adopted. The Directive on Bank Recovery and Resolution (BRRD), applicable to the entire EU, harmonized the powers and instruments of national resolution regimes and reinforced the procedures for crossborder co-operation. However, it did not set up new EU institutions, nor did it transfer competences to the EU level. Applicable only to euro area Member States, the regulation on the Single Resolution Mechanism (SRM) transferred considerable resolution competences and funding from the national level to the Banking Union level (Alexander, 2015; Howarth and Quaglia, 2014). It also created a Single Resolution Board (SRB), which can decide on the resolution of ailing banks and is responsible for managing the Single Resolution Fund (SRF).

The observed different degrees of supranationalization present important analytical puzzles. Regarding resolution, the puzzle is to explain why and how the Member States were able to overcome their long-standing sovereignty concerns, given the potential fiscal implications of a supranational regime. Even after the establishment of Economic and Monetary Union (EMU), bank supervision and resolution had remained primarily a competence of the Member States. Regarding bank structures, diverging national reforms can undermine the level playing field in the single market for financial services and create disadvantages for cross-border banks. A common EU approach, which some Member States resisted, could mitigate these problems.

What accounts for the different outcomes of low, medium and high supranationalization of the policy framework in the EU? By addressing this question, we make two contributions to the literature. First, theoretically, we draw on a synthesis of neofunctionalism and liberal intergovernmentalism to explain the diverging outcomes, focusing on how spillovers lead to preference change. In bank resolution, significant spillovers modified the preferences of the national governments of key Member States - notably Germany, France and, to a lesser extent the UK, which is outside the euro area - by changing their assessment of the costs and benefits of a supranational policy solution. The main mechanisms leading to preference change were the negative functional spillovers due to incomplete integration, most notably, the fact that competences for supervision and resolution had remained at the national level despite the intense financial integration in the EU, particularly in the euro area. There were also important positive functional spillovers resulting from newly introduced policy instruments, such as the bail-in. We explain the low supranationalization in bank structural reforms with the absence of strong spillovers and availability of domestic options to unilaterally contain financial instability. Second, empirically, we shed light on the complexity of managing the problem of 'too big to fail' in the EU by examining the sequencing of multiple interconnected reforms and 
diverging preferences of the Member States. In so doing, this article contributes to the flourishing literature on the EU's response to the international financial crisis.

The article is organized as follows: we first present different international approaches to solving the problem of 'too big to fail'; we then outline the analytical framework and explain, respectively, the post-crisis EU reforms of bank structures and bank resolution. The last section summarizes the main findings.

\section{The Conundrum of 'Too Big To Fail' in an International Perspective}

The moral hazard posed by financial institutions which are 'too big to fail' was quickly recognized by policy-makers in the aftermath of 2008. International forums, such as the Financial Stability Board (2010, p. 2) were actively engaged in drawing up best practices to mitigate this problem. The main strategy, informally known as the 'bookends approach', focused on two goals. ${ }^{1}$ The first goal was to reduce the likelihood that large financial institutions would fail. This would be accomplished by forcing banks to maintain sufficiently high capital buffers, thus enhancing their ability to absorb losses, and by preventing deposit taking institutions from engaging in 'risky' trading activities. In addition, policy-makers considered reforming bank structures to make large and complex financial institutions more easily resolvable. The second goal was to design effective resolution mechanisms that could facilitate the unwinding of distressed financial institutions without destabilizing the entire financial system.

In an international perspective, the approach taken by the United States was to update the existing legal framework regarding capital adequacy, reform the rules on bank resolution and introduce new rules on banks structures through a single comprehensive piece of legislation - the Dodd-Frank Act. Subsequently, US regulatory agencies adopted enacting legislation. By contrast, the multi-level structure of the EU and diverging preferences of the Member States led to sequential policy dynamics of first updating existing EU directives, such as the Capital Requirements Directive, followed by the negotiation of new legislation in areas such as bank resolution and reforming bank structures. As discussed in the empirical sections below, the EU approach shows the effects of sequencing and interaction of complex policy reforms. Once new EU capital and liquidity requirements were set and a common EU resolution framework was adopted, it became more difficult to agree on harmonized EU-wide bank structural reforms, not least because several Member States had already adopted such reforms domestically.

\section{Analytical Framework, Research Design and Methodology}

The analytical framework of this article builds on two bodies of literature which have been widely used to explain the progress of EU integration over time: neofunctionalism and intergovernmentalism. While the two theories are often treated as alternative explanations of the extent of European integration, we opt for a framework that brings them together for three reasons. First, this helps us to understand more precisely how crises affect policy supranationalization. Second, it enables us to address long-standing

\footnotetext{
${ }^{1}$ We thank an anonymous referee for highlighting the relevance of an international comparison.
} 
criticisms of the two approaches when they are applied independently of each other. Third, it allows us to detect and analyze the change of government preferences over time.

To elaborate on each reason in turn, first, the global financial crisis and euro area sovereign debt crisis revealed the inadequacy of the rules governing banks that were 'too big to fail' and the vulnerabilities of existing resolution regimes for cross-border banks, such as Fortis and Icesave (Kudrna, 2012). These crises, especially the sovereign debt crisis in the euro area, were the result of existing spillovers due to incomplete integration and, at the same time, amplified these spillovers (Niemann and Ioannou, 2015). Hence, to understand fully the impact of crises, we need to theorize both the different types of spillovers that have been triggered and how they affected governments' policy preferences. Like Jones et al. (2016) and Verdun (2002), we build a synthesis of neofunctionalism and intergovernmentalism to analyze the recent reform of EU banking regulation. Jones et al. (2016) examine the lowest common denominator solutions in EU banking regulation and Verdun (2002, p. 10) explains the making of Economic and Monetary Union (EMU), which represented a turning point in European economic integration.

Regarding the second reason to combine neofunctionalism and intergovernamentalism, we aim to address several long-standing criticisms of the two approaches. Intergovernamentalism has been criticized for considering national preferences as static and mostly exogenous to the integration process (Wincott, 1995). However, empirically, there are instances in which preferences on a given policy or issue have shifted because of exogenous or endogenous factors. Moreover, integovernmentalism underplays the influence of the EU institutions (Pollack, 1997; Tallberg, 2000). To address these shortcomings, we investigate whether and how government preferences about policy supranationalization changed over time due to spillover effects commonly analyzed in neofunctionalist accounts. At the same time, neofunctionalism has also been criticized for being overly deterministic. It predicts ever closer integration, whereas scholars have observed variation in the extent of integration across policy areas and issues at stake (see Hooghe and Marks, 2009; Moravcsik, 1998; Rosamond, 2000). The mechanisms through which neofunctionalism operates also tend to be underspecified. To overcome this limitation, we examine how the international financial crisis and the euro area sovereign debt crisis amplified the spillovers triggered by incomplete integration. These spillovers, in turn, modified government preferences.

Third, for heuristic purposes, we present national governments' assessment of the costs and benefits of policy supranationalization as rather 'neat'. At the same time, we recognize the relevance of uncertainty and bounded rationality in the policy process, as one should consider the possibility of miscalculation and error. We also acknowledge that government preferences are not static, especially during periods of crisis and high uncertainty. Therefore, we seek to unpack whether, and how, the costs and benefits of supranational policy solutions change over time.

Turning to the research design and propositions examined in this article, the dependent variable is the degree of policy supranationalization, which is operationalized as outlined in Table 1. The independent variables are the preferences of the national governments of key Member States concerning the degree of supranationalization in the examined policy areas. In particular, we focus on the preferences of Germany, France and the UK because the three countries are essential to move forward with a common EU policy. Under the 
Table 1: Dependent Variable: Degree of Policy Suprantionalization

\begin{tabular}{|c|c|c|}
\hline $\begin{array}{l}\text { Degree of policy } \\
\text { supranationalization }\end{array}$ & Indicators & Outcomes \\
\hline Low & $\begin{array}{l}\text { - Minimum harmonization of } \\
\text { national legislation } \\
\text { - Lowest common denominator } \\
\text { policy adopted at EU level }\end{array}$ & $\begin{array}{l}\text { Proposed regulation on bank } \\
\text { structural reforms: } \\
\text { - Brings together UK ring-fencing } \\
\text { and reforms implemented in Germany } \\
\text { and France }\end{array}$ \\
\hline Medium & $\begin{array}{l}\text { - Some harmonization of national } \\
\text { legislation mandated by new EU rules } \\
\text { - Some competences and power } \\
\text { transferred to the EU level }\end{array}$ & $\begin{array}{l}\text { BRRD (all EU Member States): } \\
\text { - Harmonization of resolution tools } \\
\text { and powers } \\
\text { - Introduction of bail-in }\end{array}$ \\
\hline High & $\begin{array}{l}\text { - Maximum harmonization of national } \\
\text { legislation mandated by new EU rules } \\
\text { - Extensive transfer of power and } \\
\text { competences to the EU level } \\
\text { - Creation of new EU institutions }\end{array}$ & $\begin{array}{l}\text { SRM regulation (Banking Union):** } \\
\text { - Reproducing BRRD provisions to } \\
\text { enhance harmonization } \\
\text { - Limited national discretion } \\
\text { - Creation of SRB and SRF }\end{array}$ \\
\hline
\end{tabular}

** In addition to the Single Resolution Mechanism (SRM), the Single Supervisory Mechanism (SSM) is another example of a high degree of supranationalization in EU banking regulation, as discussed in the section on resolution.

current QMV voting rules in the Council, these three countries, together with any other EU Member State, have a sufficient number of votes to block any proposed piece of legislation. We analyze the revealed preferences of national governments on EU policy supranationalization by drawing on primary sources, first and foremost the responses to the Commission's public consultations, public statements, policy documents, and a systematic survey of press coverage. Several semi-structured interviews with policymakers were carried out to cross-check these findings.

In line with a rationalist approach, we assume that Member State governments engage in a cost-benefit analysis of supranationalization in each policy area. In comparison to other policy domains, banking regulation stands out as an area in which the distributional consequences of policy choices are relatively clear. We seek to unpack the causal relationship between government preferences and level of policy supranationalization. Governments have to strike a balance between protecting domestic financial stability, which might require the supranationalization of certain policy areas, while delimiting the negative domestic distributional consequences of doing so. To take into account the role of domestic political economy, we draw on the insights of liberal intergovernmentalism about the importance of domestic interest groups, such as the financial sector (Howarth and Quaglia, 2016; Moravcsik, 1998; Schimmelfennig, 2015). We consider the positions of important domestic stakeholders in our empirical analysis, as they matter for governments' evaluation of the costs and benefits of further policy supranationalization. Still, scholars have also found that governments are able to marginalize the influence of the financial industry and build momentum for regulatory reform (see James, 2016).

To be precise, what are the costs and benefits that inform governments' willingness to agree to supranational policy solutions? The main benefits are to secure financial stability by transferring powers and pooling financial resources at the EU level, together with the 
establishment of new EU bodies, which also facilitate the cross-border activities of the financial industry (Schoenmaker, 2013). Some Member States might also benefit from redistributive implications related to the pooling of resources at the EU level. The main costs are the reduction of national policy autonomy, which also limits the room for manoeuvre of the national competent authorities, and adjustments costs for the financial industry, especially for domestic banks (Spendzharova, 2014). Some Member States might also be potential losers from redistributive implications related to the pooling of resources at the EU level. We operationalize the assessment of costs and benefits by examining the political economy effects of EU rules on bank structures and resolution in the empirical sections.

\section{Proposition 1: The national governments of EU Member States agree to supranationalize areas of banking regulation when the benefits of a supranational policy solution outweigh the incurred costs.}

Taking into account the important criticism that national preferences are not static, we draw on neofunctionalism to theorize how spillovers can modify the preferences of national governments over time. Neofunctionalism considers three different types of 'spillovers' (Haas, 1958, 1966; Niemann and Ioannou, 2015). 'Functional spillovers' are driven by economic dynamics in the policy field and result from previous but incomplete integration. Negative functional spillovers emerge when the EU Member States are unable to solve policy problems unilaterally at the domestic level. These spillovers shift national preferences in favour of more integration to avoid the losses deriving from stagnation or even disintegration, as in the case of the sovereign debt crisis (see Niemann and Ioannou, 2015; Schimmelfennig, 2015). Certain spillovers are greater for euro area insiders than outsiders. For example, exogenous shocks and the incomplete institutional set up of EMU put pressure on euro area insiders to move ahead with further integration to 'fix the problem' and avoid the costs of breakdown (Schimmelfennig, 2016). Positive functional spillovers result from integration proceeding in functionally related policy areas. Agreement to delegate power to the EU level in a certain policy area reduces the costs of introducing supranational solutions in functionally related policy areas. Drawing on Niemann and Ioannou (2015, p. 200) we operationalize functional spillovers by looking at 'the salience of the original goal', 'the existence of functional interdependence between issue A (original objective) and issue B (requiring further action)', and the 'availability of functional solutions' at the national level.

'Political spillovers' derive from the preferences of business interest groups and civil society about policy supranationalization. In particular, transnational economic interest groups and companies engaged in cross-border business tend to support further integration that facilitates gains from economies of scale, for example, by reducing the costs of having to comply with a variety of different national regulations (Sandholtz and Zysman, 1989). This was notably the case in the relaunch of the single financial market (see Mügge, 2010). We operationalize this type of spillover by teasing out the preferences of large internationalized banks, based on responses to stakeholder consultations and other public statements.

Lastly, 'cultivated spillovers' are generated by the preferences and active efforts of supranational actors, such as the European Commission and more recently the ECB, to 
boost the integration process (see also Niemann and Ioannou, 2015). For example, scholars have shown that the Commission and the ECB acted as major entrepreneurs in the making of the European Banking Union (De Rynck, 2016; Epstein and Rhodes, 2016; McPhilemy, 2016). We operationalize this type of spillover by examining the role of the Commission and the ECB, in particular, in any initiatives promoting further policy supranationalization.

Proposition 2: Spillover effects can alter the assessment of costs and benefits for national governments concerning further policy supranationalization.

After outlining our analytical framework, we consider two alternative explanations. First, the sequencing of domestic and EU regulatory reforms can affect the level of policy supranationalization through the 'first mover advantage' (see Héritier, 1996; James, 2015). Reforms already implemented at the domestic level can constrain the degree of policy supranationalization at the EU level. We observe this dynamic in the case of bank structural reforms, where the UK, France and Germany adopted domestic legislation before any common EU legislation. Subsequently, they insisted on minimum harmonization at the EU level. However, resolution contradicts this expectation. Even though the UK and, to a lesser extent, Germany reformed their domestic legislation on bank resolution before any common EU rules, they did not insist on watering down the proposed EU legislation. On the contrary, the UK (see James, 2015) and, later on, Germany were important proponents of creating a more supranationalized resolution framework by adopting the BRRD. The second alternative explanation refers to political salience (Woll, 2013) and would anticipate a lower degree of supranationalization in policy areas with high salience and diverging government preferences. The policy outcome we observe in resolution contradicts this expectation. Resolution has high salience for politicians and public opinion, as it entails the possibility of bank bail-outs or closing down banks. However, eventually, the Member States agreed to a high degree of supranationalization of the policy framework.

\section{The Reform of Bank Structures in the EU}

The proposed regulation on 'Structural Measures Improving the Resilience of EU Credit Institutions', currently under negotiation, is the linchpin of the post-crisis reform of the EU rules on bank structure. The regulation introduces minimum harmonization measures, reflecting the lowest common denominator of the different national government preferences. Indeed, the official proposal, as modified by the Council in 2015, implies a lower degree of EU harmonization than the recommendations of the 2012 Liikanen report, which informed the Commission's original legislative proposal in 2014. We argue that the explanation for the observed minimum harmonization is twofold: a lack of major spillovers from previous integration and the fact that, for the majority of national governments, the costs of extensive supranationalization outweighed the benefits.

Unlike in the case of bank resolution discussed in the following sections, there were no strong positive or negative spillovers from previous integration in the area of bank structural reform. Preceding EU legislation in the realm of banking regulation and supervision, such as the Capital Requirements Directive IV (CRD IV) and the Single 
Supervisory Mechanism (SSM) Regulation, offered large internationalized banks the advantages of a European level playing field, a single supervisory contact point and a single rulebook in banking (see Grossman and Leblond, 2011; Macartney, 2010; Mügge, 2010; Posner and Véron, 2010; Quaglia, 2010). By contrast, the proposed legislation on bank structure did not contain similar benefits regarding a level playing field across the EU. Instead, it involved high compliance costs and restructuring costs for banks, especially universal ones (PriceWaterhouseCoopers, 2014). The literature has also identified a negative effect of bank separation on risk diversification within the banking group and the level of intermediation in the broader economy (Hakenes and Schnabel, 2014; Huertas, 2015).

Furthermore, national governments were less exposed to negative spillovers in the case of bank structures, because they could take unilateral domestic action to tackle this problem. Indeed, the British, French and German governments passed domestic banking structural reforms in the aftermath of the 2008 financial crisis (see Hardie and Macartney, 2016; James, 2015). We show below that these governments sought to minimize their compliance costs and negotiate EU rules compatible with their domestic status quo.

In February 2012, Michel Barnier, then EU Commissioner for Internal Market and Services, established a High-level Expert Group (HLEG) on structural bank reforms to assess the need for additional reforms directly targeted at the structure of individual banks (Liikanen, 2012, p. i). The HLEG recommended a set of five ambitious measures which aimed to make banking groups, especially their core deposit-taking and retail banking operations, safer and less connected to high-risk trading activities (Liikanen, 2012, p. iii). This, in turn, would limit the implicit or explicit stake of taxpayers in the investment parts of banking groups.

Building on the Liikanen report, the Commission put forward an EU legislative proposal for a regulation on reforming bank structures in 2014, after the British, French and German governments had already adopted and implemented domestic reforms in this area. The Commission's proposal focused on a ban on proprietary trading and separation of certain trading activities from the deposit-taking entity. The proposal would directly affect the activities and structure of large globally active EU banks exceeding certain thresholds, such as $€ 30$ billion in total assets, and trading activities either exceeding $€ 70$ billion or 10 per cent of the bank's total assets (European Commission, 2014). Under the new rules, these banks would face severe restrictions on proprietary trading, meaning 'positions taken for making a profit for the bank's own account, without any connection to client activity, the hedging of the bank's risk or for cash management purposes' (European Commission, 2014, p. 7).

Disagreeing with the Commission's proposal outlined above, the Council put forward its own two solutions in June 2015. One possibility was to force banks to separate trading activities in an entity legally, economically and operationally separate from the credit institution that carries out core retail banking activities (Council, 2015, p. 6). This was in line with the measures already adopted in Germany and France. The other option was to ring-fence core retail banking activities in accordance with national law (Council, 2015, p. 6). This corresponded to the reforms already in place in the UK. At the time of writing, the European Parliament has not yet reached an agreement with the Council on the amendments to the Commission's original legislative proposal. 
The national governments of key Member States did not support extensive EU harmonization because the benefits would be low and the costs would be high, in particular for universal banks. It is noteworthy that the preferences of the French, German and UK governments strongly resembled those of their domestic banking industry and did not change over time. The French and German governments were concerned about the costs of compliance for banks and the broader negative effects that stricter EU banking structural reforms would have on the viability of the universal banking model, which is very important for continental banking systems (see Hardie and Macartney, 2016; Howarth and Quaglia, 2016). The Franco-German joint response to the public consultation on EU banking structural reforms, stressed that '[a]ny structural banking reform must respect the diversity of the European banking system, including the business model of the savings banks as well as the mutual and cooperative banks' (Joint German and French Response, 2013, p. 2). This position strongly resonated with the statements of domestic stakeholders, such as that of French-based Crédit Agricole (2013, p. 4) which highlighted that the EU reforms 'would run the risk of disrupting the market in a fragile economic context, driving costs upwards, raising uncertainty among clients and investors, and hampering efforts towards economic growth'.

Likewise, the UK government sought to ensure that the forthcoming EU legislation did not add further requirements to the already adopted ring-fencing reforms (Hardie and Macartney, 2016; Howarth and Quaglia, 2016; James, 2015). This stance resonated with the preferences of major UK-based banks, such as Standard Chartered, Barclays and the Royal Bank of Scotland (RBS). For example, Standard Chartered (2013, p. 1) asserted that 'structural reform is unnecessary to improve financial stability and address systemic risk ... there is no clear evidence to support the case for structural reform.' RBS (2013, p. 1) warned against the cost of 'multiple, inconsistent variants of structural reform'.

In contrast to other areas of banking regulation, such as capital requirements and resolution, large international and regional banks such as Deutsche Bank, UniCredit, Standard Chartered, RBS Group, Nordea and SEB opposed bank structural reforms at the EU level (Howarth and Quaglia, 2016). Moreover, associations representing small mainly domestic banks took a similar stance. One such association is the German Banking Industry Committee, which brings together the central associations of the German banking industry representing over 2,000 private commercial banks, co-operative banks, public-sector banks and savings banks. In its public consultation response, it highlighted the importance of diversity of national banking structures across the EU to ensure financial stability (GBIC, 2013).

\section{The Reform of Bank Resolution in the EU}

\section{The BRRD}

The BRRD, adopted in 2014, regulated bank resolution in the EU for the first time, harmonizing resolution instruments and powers, and introducing an important new instrument, the bail-in. Hence, it represents a case of medium supranationalization. We argue that the observed outcome is explained by the negative and positive spillovers from previous incomplete integration and by the fact that, largely as a result of those spillovers, the benefits of (medium) supranationalization for national governments of key Member 
States came to outweigh the costs. EU financial integration increased substantially following the 'completion of the Single Financial Market' in the 2000s (Grossman and Leblond, 2011; Macartney, 2010; Mügge, 2010; Quaglia, 2010). Cross-border banking intensified, especially in the euro area, following the establishment of EMU in 1999 (Howarth and Quaglia, 2016).

Yet, EU rules on resolution did not keep up with the pace of financial integration: Many banks operated across the EU, but there was not a harmonized set of instruments and powers to resolve them. Effective arrangements for cross-border co-operation were also lacking (Kudrna, 2012). Hence, there was a 'financial trilemma' between financial stability, financial integration and national policies for supervision and resolution (Schoenmaker, 2013). This trilemma, which applied internationally, was particularly acute in the EU, especially in the euro area, given the high level of financial integration (Howarth and Quaglia, 2016). The salience of the original goal (the Single Financial Market and EMU), the link between this original objective and the new issue of how to resolve cross-border banks, together with the lack of a functional solution at the national level, generated functional spillovers, paving the ground for post-crisis EU rules on resolution. $^{2}$

The negative functional spillovers that first came to the fore during the international financial crisis of 2007-08 changed the preferences of the national governments of key Member States in favour of (limited) supranationalization, meaning EU harmonization of instruments and powers, because the benefits ensuing from this solution increased and the costs diminished. The benefits increased because the new EU rules would provide a harmonized set of instruments and powers to resolve cross-border banks on a regional scale, given the high level of EU financial integration (on the disastrous case of Fortis, see Kudrna, 2012). At the same time, the costs of harmonization diminished because national resolution regimes had been proven unfit for purpose by the crisis. In the past, the diversity of national resolution regimes had made even minimum EU harmonization challenging. It took more than 10 years to negotiate the Directive on the Winding up of credit institutions (2001), which was based on minimum harmonization. Confronted with the imminent failure of large cross-border banks during the crisis, the national governments of key Member States, which had very different national regimes in place, searched for new or revised resolution instruments and powers at the EU level.

In the aftermath of the international financial crisis, the Commission issued a 'Public Consultation regarding an EU Framework for Cross-Border Crisis Management in the Banking Sector' in October 2009 (European Commission, 2009). The responses highlighted that the reform of the EU bank resolution regime was supported in principle by the national governments and the financial industry, but it was fraught with difficulties in practice. There was general agreement on the harmonization of instruments and powers, albeit most governments and domestic banks were in favour of minimum rather than maximum harmonization. At the same time, the national governments of key Member States opposed the supranationalization of resolution through the establishment of a European Resolution Authority (ERA), a European Resolution Fund (ERF) and

\footnotetext{
${ }^{2}$ For a similar argument with reference to the euro area crisis, see Niemann and Ioannou (2015) and Schimmelfennig $(2015,2016)$.
} 
burden-sharing. Some national governments anticipated high costs due to the potential fiscal implications of resolving banks and limited benefits. At the time, the sovereign debt crisis and its bank-sovereign doom loop had not yet come to light.

For example, the German government (2010, p. 2) pointed out that 'an ERA would impinge upon the autonomy of the member states ... and there is the danger that the measures taken would affect the national budget' (authors' translation). Similar points were made by the Austrian, Dutch and Finnish governments in their responses to the public consultation. The UK authorities (UK Treasury, Financial Services Authority, Bank of England, 2010, p. 3) explained that an ERA 'would be a big step with fiscal implications for Member States, as responsibility for providing financial assistance to institutions ultimately lies with national fiscal authorities and tax-payers'. The French government (2010) did not take a position on an ERA/ERF. The preferences of these national governments were mostly in line with those of their national financial industry. However, large cross-border banks were well-disposed towards maximum harmonization, which would facilitate their cross-border activities and guarantee a level playing field (BNP Paribas, 2010; Deutsche Bank, 2010; ING, 2010).

Faced with this strong opposition to maximum harmonization by key national governments, the Commission set aside the controversial supranational elements, focusing instead on the harmonization of instruments and powers. In April 2011, it issued a second public consultation on the technical details of a possible European crisis management framework (European Commission, 2011). The main innovation was the instrument of 'bail-in', which gave the resolution authorities the statutory power to write off equities and write down or convert debt into equities as a means of recapitalizing an ailing financial institution, without the injection of public funds (known as a bail-out).

By and large, the national governments of key Member States were in favour of the bail-in, but pointed out in their consultation responses that this instrument was untested and could have negative unintended effects. The financial industry expressed strong reservations about the bail-in, highlighting that it would increase the funding cost of banks. The European Banking Federation (2011) regarded it as a 'last recourse action', to be used in a gone concern phase of resolution but not as an option for going concern (see also BNP Paribas, 2011; Intesa, 2011; Unicredit, 2011). Deutsche Bank (2011, p. 4) demanded a 'transition period of at least 10 years'. For $\operatorname{HSBC}(2011$, p. 2), 'the authorities should not discard short-term taxpayer intervention as a tool'.

The Commission put forward the official proposal for the BRRD in 2012. In its impact assessment, the Commission (2012, p. 12) pointed out two main 'drivers' of the proposal: i) the 'divergence and lack of effective resolution tools and powers across the member states'; and ii) the 'misalignment between national accountability and the mandate of authorities and cross-border nature of the industry'. It acknowledged that the BRRD could solve the first problem, but not the second one. The directive proposed the setting up of national resolution funds, but there was no agreement on the 'format': the German and Dutch governments preferred ex-ante resolution funds separated from deposit guarantee schemes; the British and Italian governments favoured ex-post funds merged with deposit guarantee schemes. The possibility of merging the resolution fund and the deposit guarantee fund was also supported by the French government (EUObserver, 21 June 2013). The second controversial issue in the BRRD negotiations concerned the degree of 
national flexibility in the use of bail-in as well as the hierarchy in the bailing-in of creditors. The British, French and Swedish governments preferred - for different reasons - more flexibility about when and how to use the bail-in. The German, Dutch, Finish and Danish governments favoured harmonized rules with limited flexibility (Financial Times, 13 October 2013; Howarth and Quaglia, 2016).

\section{The SRM}

The SRM regulation, applicable to Member States in the euro area, transferred resolution powers and funding from the national to the euro area level and set up a new EU body with decision-making competences in resolution, the SRB. The regulation deliberately reproduced many provisions of the BRRD, narrowing down the room for manoeuvre in the national implementation of the directive. Furthermore, the SRB is responsible for managing the newly created Single Resolution Fund (Alexander, 2015; Howarth and Quaglia, 2014). Hence, the outcome of the reform was a high degree of supranationalization of bank resolution in the euro area (to be precise, in Banking Union). The SRM was one of the three components of Banking Union, proposed in June 2012.

The euro area sovereign debt crisis, which reached its peak in 2012 and threatened the very survival of the euro, triggered considerable negative spillovers and gave new momentum to the supranationalization of resolution in the euro area. The main functional spillover was generated by the so-called 'doom loop' between banks and sovereigns in the periphery of the euro area. The 'doom loop' worked as follows: ailing banks were rescued by their sovereigns, whose fiscal positions were weakened by the costs of bail-outs. At the same time, sovereigns in a weak fiscal position received a downgrade of their bonds which, in turn, reduced the capital base of (mostly national) banks holding government bonds. Consequently, the sovereigns experienced further pressure to prop up the banks, which led to even greater worsening of the national fiscal positions (Véron, 2012). Initially, the 'doom loop' was a direct problem for the euro area periphery hit by the crisis. However, over time, it also became an indirect problem for core euro area countries, given the high level of financial interpenetration and the ultimate threat of EMU break-up (Howarth and Quaglia, 2016; Leblond, 2014).

The salience of the original objective (EMU), functional interdependencies between EMU and the sovereign debt crisis, which threatened the very survival of the euro, and the lack of functional solutions at the national level generated negative functional spillovers. These spillovers increased the benefits of supranationalizing supervision and resolution in the euro area (see also Schimmelfennig 2015, 2016). Furthermore, resolution poses an issue of cross-border legal powers that cannot be addressed simply by harmonization (for instance, the BRRD). Hence, the euro area Member States opted for a supranational solution, where the SRB can compel the national authorities to act together. ${ }^{3}$ The supranationalization of bank supervision as part of Banking Union decreased the costs of supranationalizing bank resolution for Member State governments that had opposed an ERA and an ERF in the past. Before the proposal for Banking Union was put forward, the German government had repeatedly pointed out the need to have the responsibility for supervision and resolution at the same level of governance, so as to

\footnotetext{
${ }^{3}$ We thank an anonymous referee for bringing up this point.
} 
avoid moral hazard. In other words, it opposed the idea of pooling national financial resources at the EU level to pay for the resolution of banks across the EU, which were not subject to common supervision (Schäfer, 2016). However, once supervision was transferred to the euro area level, resolution had to follow. At the same time, 'differentiated integration' in the EU due to EMU membership generated different spillovers for the euro area insiders and outsiders (Schimmelfennig, 2016). Euro area outsiders, first and foremost the UK, were not directly exposed to these EMU-related spillovers. By and large, they supported the project of Banking Union and the SRM as a way to stabilize the euro area and solve the crisis (Howarth and Quaglia, 2016).

A cultivated spillover then kicked in: once the ECB gained supervisory competences in the SSM, the Bank became one of the main advocates for setting up of the SRM. In its legal opinion on the establishment of the SRM, the ECB (2013, p. 3) highlighted that 'the SRM is a necessary complement to the SSM, as the levels of responsibility and decision-making for resolution and supervision have to be aligned'. During the negotiations of the SRM, ECB President Mario Draghi pointed out that 'We should not create a Single Resolution Mechanism that is single in name only ... I urge you and the Council to swiftly set up a robust Single Resolution Mechanism, for which three elements are essential in practice: a single system, a single authority, and a single fund' (Bloomberg, 16 December 2013).

In July 2013, the Commission proposed the establishment of the SRM, designed to complement the SSM. The initial proposal, supported by the French, Spanish and Italian governments, gave the Commission the final power to decide whether to place a bank into resolution and determine the application of appropriate resolution tools. However, the German government argued the Single Resolution Board (SRB) should be given this power. Furthermore, the legislation proposed the establishment of the Single Resolution Fund (SRF) financed by bank levies raised at the national level. The national compartments would then be pooled into a single fund. In this respect, the German government worried about the moral hazard resulting from the mutualization of risks and, therefore, insisted on setting up the fund through an intergovernmental agreement among the participating Member States (Howarth and Quaglia, 2014, 2016).

The new instrument of bail-in, introduced in the BRRD, became a 'game changer' (Smeets and Nielsen, 2016) in the realm of bank resolution because it moved the negotiations away from lowest common denominator toward a more supranational policy solution. Importantly, we explain below how the bail-in reduced the costs of supranationalizing resolution in the euro area for countries in a strong fiscal position. Hence, there was a positive spillover between the BRRD and the SRM regulation, which were indeed adopted at the same time.

The governments of Member States with stable banking systems and a strong fiscal position, such as Germany, Austria, Finland and the Netherlands sought to avoid fiscal transfers to euro periphery countries hit by the sovereign debt crisis and the 'doom loop'. These governments initially opposed the supranationalization of resolution, to be precise the ERA, the ERF and burden sharing, because of the potential fiscal implications. As summarized by an interviewee, 'it is generally unpopular to bail out banks, it is even more unpopular to bail out banks in other countries'. The introduction of the bail-in tool reduced substantially the need for public funding to bail out banks. Thus, the SRM could be 'fiscally neutral' (Eurogroup and Ecofin, 2013, p. 1), which alleviated the initial 
reservations of key national governments. Indeed, once the SRM regulation was proposed, the German government, supported by the Dutch, Austrian and Finnish governments, even insisted on an earlier entry into force of the bail-in than the date in 2018 originally envisaged. The start date was eventually moved forward to 2016 (The Economist, 14 December 2013).

However, the structural difficulty of breaking the 'doom loop' was revealed as soon as the bail-in principle had to be applied in practice. In 2015, the European Banking Authority stress test and the ECB asset quality review showed that several Italian banks suffered from non-performing loans. In cases such as Monte dei Paschi di Siena, the viability of the bank was at risk (De Groen and Gros, 2016). The matter was complicated by the entry into force of the BRRD because in the past Italian banks had (mis-)sold considerable amounts of subordinated debt to small savers who were not aware of the risk that this debt carried. Consequently, bank bond holders were subject to bail-in and some small savers would lose their lifetime savings, which caused public outrage. Ignazio Visco, the Governor of the Bank of Italy, pointed out that during the negotiation of BRRD, the Italian authorities 'argued, without finding the necessary support, that the immediate application and, above all, the retroactive application of the burden-sharing mechanisms through 2015 and, later, the bail-in could result in risks to financial stability' (Visco, 2016, authors' translation). He added that a longer transition period and a more narrowly targeted application of the bail-in would be preferable. Consequently, in early 2016, the Italian authorities called for a revision of the $\mathrm{BRRD}$, or at least a longer transition period.

\section{Conclusion}

We set out to explain the different degrees of progress towards a supranational framework in two important areas of regulation for banks that are 'too big to fail': Bank resolution and bank structures. We found low supranationalization concerning the regulation on bank structural reforms, medium supranationalization concerning the BRRD and high supranationalization concerning the SRM. We explained these diverging outcomes by identifying how spillovers changed national governments' assessment of the costs and benefits of policy supranationalization, thus reshaping their preferences over time.

The main mechanisms leading to preference change in the case of resolution were the negative functional spillovers due to previous incomplete integration and positive functional spillovers resulting from new policy instruments, first and foremost the bail-in. Political spillovers in the area of resolution derived from the fact that large cross-border banks actively endorsed the supranationalization of resolution. Cultivated spillovers were generated by the Commission's entrepreneurship and, later on, the ECB's entrepreneurship with specific reference to the SRM. Neofunctionalism captures well the pressures to keep the momentum of the integration process, but the national governments of the Member States are not simply at the mercy of structural forces. They weigh the costs and the benefits of supranational policy solutions before agreeing to delegate authority to the EU level. As we saw in the case of bank structural reforms, when governments have domestic options to unilaterally contain financial instability, they seek, at best, minimum harmonization at the EU level. Regarding the broader significance of the findings, a similar analytical approach could explain the failure (so far) to adopt a common European deposit insurance scheme, which would complete the Banking Union. 
Correspondence:

Aneta Spendzharova

Political Science Department

Maastricht University

P.O. Box 616

6200 MD Maastricht, The Netherlands

email: a.spendzharova@maastrichtuniversity.nl

\section{References}

Alexander, K. (2015) 'European Banking Union: A Legal and Institutional Analysis of the Single Supervisory Mechanism and the Single Resolution Mechanism'. European Law Review, Vol. 40, No. 2, pp. 154-87.

Bernanke, B. S. (2010) 'Causes of the Recent Financial and Economic Crisis Before the Financial Crisis Inquiry Commission’. Washington, D.C., September 2, 2010.

BNP Paribas (2010) 'Response to the Commission's consultation', 12 March.

BNP Paribas (2011) 'Response to the Commission's consultation', 6 May.

Crédit Agricole (2013) 'Response to the Commission's consultation', 11 July.

Council of the European Union (2015) 'Council Position on Proposal for a Regulation of the European Parliament and of the Council on Structural Measures Improving the Resilience of EU Credit Institutions', 10089/15, 19 June.

Deutsche Bank (2010) 'Response to the Commission's consultation', 12 March.

De Larosière, J. et al. (2009) 'Report of the High-level Group on Financial Supervision in the EU', Brussels. Available online at: http://ec.europa.eu/internal_market/finances/docs/ de_larosiere_report_en.pdf. Last accessed: 5 May 2016.

De Groen, W.P. and Gros, D. (2016) The continuing saga of Banca Monte dei Paschi di Siena (CEPS Commentary Series) (Brussels: CEPS) 28 July.

De Rynck, S. (2016) 'Banking on a Union: The Politics of Changing Eurozone Banking Supervision'. Journal of European Public Policy, Vol. 23, No. 1, pp. 119-35.

Epstein, R.A. and Rhodes, M. (2016) 'The Political Dynamics Behind Europe's New Banking Union'. West European Politics, Vol. 39, No. 30, pp. 415-37.

Eurogroup and Ecofin Council (2013) 'Statement on the SRM Backstop', 17983/, 18 December.

European Association of Co-operative Banks (2013) 'Response to the Commission's consultation', 11 July.

European Banking Federation (2011) 'Response to the Commission's consultation', 6 May.

European Central Bank (2013) 'Opinion on the Establishment of the Single Resolution Mechanism', 6 November, Frankfurt.

European Commission (2009) 'Consultation regarding an EU framework for Cross-Border Crisis Management in the Banking Sector', $\operatorname{COM}(2009)$ 561, 20 October.

European Commission (2011) 'Consultation on the Technical Details of a Possible European Crisis Management Framework', IP/11/10, 6 January.

European Commission (2012) 'Impact Assessment of the BRRD', SWD(2012) 166, 6 June.

European Commission (2014) 'Proposal on Banking Structural Reform', 2014/0020 (COD). Available online at: http://ec.europa.eu/finance/bank/structural-reform/index_en.htm. Last accessed: 10 October 2016.

Financial Services Authority (FSA) (2009) The Turner Review: A Regulatory Response to The Global Banking Crisis (London: FSA).

Financial Stability Board (2010) 'Reducing the Moral Hazard Posed by Systemically Important Financial Institutions', Basel, 20 October.

French Government (2010) 'Response to the Commission's consultation', 12 March. 
German Banking Industry Committee (GBIC) (2013) 'Response to the Commission's consultation', 11 July.

German Government (2010) 'Response to the Commission's consultation', 12 March.

Grossman, E. and Leblond, P. (2011) 'European Financial Integration: Finally the Great Leap Forward?' JCMS, Vol. 49, No. 2, pp. 413-35.

Haas, E. (1958) The Uniting of Europe: Political, Social and Economic Forces, 1950-1957 (Stanford, CA: Stanford University Press).

Hardie, I. and Macartney, H. (2016) 'EU Ring-Fencing and The Defence Of Too-Big-To-Fail Banks'. West European Politics, Vol. 3, No. 30, pp. 503-25.

Héritier, A. (1996) 'The Accommodation of Diversity in European Policy-Making and its Outcomes: Regulatory Policy as a Patchwork'. Journal of European Public Policy, Vol. 3, No. 2, pp. 149-67.

Hooghe, L. and Marks, G. (2009) 'A Postfunctionalism Theory of European Integration: From Permissive Consensus to Constraining Dissensus'. British Journal of Political Science, Vol. 39, No. 1, pp. 1-23.

Howarth, D. and Quaglia, L. (2013) 'Banking on Stability: The Political Economy of New Capital Requirements in the European Union'. Journal of European Integration, Vol. 35, No. 3, pp. 333-46.

Howarth, D. and Quaglia, L. (2014) 'The Steep Road to Banking Union: The Setting Up of the Single Resolution Mechanism'. JCMS Annual Review, Vol., Vol. 50, No. s1, pp. 125-40.

Howarth, D. and Quaglia, L. (2016) The Political Economy of Banking Union (Oxford: Oxford University Press).

HSBC (2011) 'Response to the Commission's consultation', 6 May.

Huertas, T.F. (2015) 'Six Structures in Search of Stability', LSE Financial Markets Group Paper Series, Special Paper No. 236, July.

ING (2010) 'Response to the Commission's consultation', 12 March.

Intesa (2011) 'Response to the Commission's consultation', 6 May.

Ioannou, D., Leblond, P. and Niemann, A. (2015) 'European Integration and the Crisis: Practice and Theory'. Journal of European Public Policy, Vol. 22, No. 2, pp. 155-76.

James, S. (2015) 'The UK in the Multilevel Process of Financial Market Regulation: Global Pace-Setter or National Outlier?' In Maynz, R. (ed.) Multilevel Governance of Financial Market Reform (Max Planck Institute: Cologne).

James, S. (2016) 'The Domestic Politics of Financial Regulation: Informal Ratification Games and the EU Capital Requirement Negotiations'. New Political Economy, Vol. 21, No. 2, pp. 187-203.

Joint German and French Response (2013) 'Response to Consultation by the Commission on the Structural Reform of the Banking Sector', 11 July.

Jones, E., Kelemen, D. and Meunier, S. (2016) 'Failing Forward? The Euro Crisis and the Incomplete Nature of European Integration'. Comparative Political Studies, Vol. 49, No. 7, pp. 1010-34.

Kudrna, Z. (2012) 'Cross-Border Resolution of Failed Banks in the European Union after the Crisis: Business as Usual'. JCMS, Vol. 50, No. 2, pp. 283-99.

Leblond, P. (2014) 'The Logic of a Banking Union for Europe'. Journal of Banking Regulation, Vol. 15, No. 3/4, pp. 288-98.

Liikanen, E. et al. (2012) Report of the High-level Expert Group on Reforming the Structure of the EU Banking Sector (Brussels).2 October

Macartney, H. (2010) Variegated Neoliberalism: Convergent Divergence in EU Varieties of Capitalism (London: Routledge).

McPhilemy, S. (2016) 'Integrating Macro-Prudential Policy: Central Banks As The 'Third Force' In EU Financial Reform'. West European Politics, Vol. 39, No. 30, pp. 526-44. 
Moravcsik, A. (1998) The Choice for Europe. Social Purpose and State Power from Messina to Maastricht (Ithaca, NY: Cornell University Press).

Mügge, D. (2010) Widen the Market, Narrow the Competition: Banker Interests and the Making of a European Capital Market (Colchester: ECPR Press).

Niemann, A. and Ioannou, D. (2015) 'European Economic Integration In Times Of Crisis: A Case Of Neofunctionalism?' Journal of European Public Policy, Vol. 22, No. 2, pp. 196-218.

Pollack, M. (1997) 'Delegation, Agency, and Agenda-Setting in the European Community'. International Organization, Vol. 51, No. 1, pp. 99-134.

Posner, E. and Véron, N. (2010) 'The EU and Financial Regulation: Power Without Purpose?' Journal of European Public Policy, Vol. 17, No. 3, pp. 400-15.

PricewaterhouseCoopers (2014) 'Impact of Bank Structural Reforms in Europe', Report for AFME, 25 November.

Quaglia, L. (2010) Governing Financial Services in the European Union (London: Routledge).

Royal Bank of Scotland (RBS) (2013) 'Response to the Commission's consultation', 12 July.

Sandholtz, W. and Zysman, J. (1989) '1992: Recasting the European Bargain'. World Politics, Vol. 42, No. 1, pp. 95-128.

Schäfer, D. (2016) 'A Banking Union of Ideas? The Impact of Ordoliberalism and the Vicious Circle on the EU Banking Union'. JCMS. DOI:10.1111/jcms.12351.

Schimmelfennig, F. (2015) 'Liberal Intergovernmentalism and the Euro Area Crisis'. Journal of European Public Policy, Vol. 22, No. 2, pp. 177-95.

Schimmelfennig, F. (2016) 'A Differentiated Leap Forward: Spillover, Path-Dependency, and Graded Membership in European Banking Regulation'. West European Politics, Vol. 39, No. 30, pp. 483-502.

Schoenmaker, D. (2013) Governance of International Banking: The Financial Trilemma (Oxford: Oxford University Press).

Smeets, S. and Nielsen, B. (2016) 'The Role of the EU Institutions in Setting Up the Banking Union. Collaborative Institutional Leadership in the EMU Reform Process'. Paper presented at the ECPR Joint Sessions of Workshops, Pisa, 24-28 April.

Spendzharova, A. (2014) 'Banking Union under Construction: The Impact of Foreign Ownership and Domestic Bank Internationalization on European Union Member States' Regulatory Preferences in Banking Supervision'. Review of International Political Economy, Vol. 21, No. 4, pp. 949-79.

Standard Chartered (2013) 'Response to the Commission's consultation', 12 July.

Tallberg, J. (2000) 'The Anatomy of Autonomy: An Institutional Account of Variation in Supranational Influence'. JCMS, Vol. 38, No. 5, pp. 843-64.

Unicredit (2011) 'Response to the Commission's consultation', 6 May.

UK Treasury, Financial Services Authority, Bank of England (2010) 'Response to the Commission's consultation', 12 March.

Verdun, A. (2002) 'Merging Neofunctionalism and Intergovernmentalism: Lessons from EMU'. In Verdun, A. (ed.) The Euro: European Integration Theory and Economic and Monetary Union (Oxford: Rowman and Littlefield Publishers), 99-28-28.

Véron, N. (2012) 'Europe's Single Supervisory Mechanism and the Long Journey towards Banking Union'. Briefing Paper for the European Parliament. Available online at: http://www. europarl.europa.eu/document/activities/cont/201210/20121003ATT52841/ 20121003ATT52841EN.pdf. Last accessed: 10 October 2016.

Visco, I. (2016) Speech at $22^{\circ}$ Congresso ASSIOM Forex, Torino, 30 January.

Wincott, D. (1995) 'Institutional Interaction and European Integration: Towards an Everyday Critique of Liberal Intergovernmentalism'. JCMS, Vol. 33, No. 4, pp. 597-60.

Woll, C. (2013) 'Lobbying under Pressure: The Effect of Salience on European Union Hedge Fund Regulation'. JCMS, Vol. 51, No. 3, pp. 555-72. 